\title{
Reseña del libro Urdimbre de la Imagen. Aportes para la enseñanza de la historia de Carlos A. Flórez López (2020)*
}

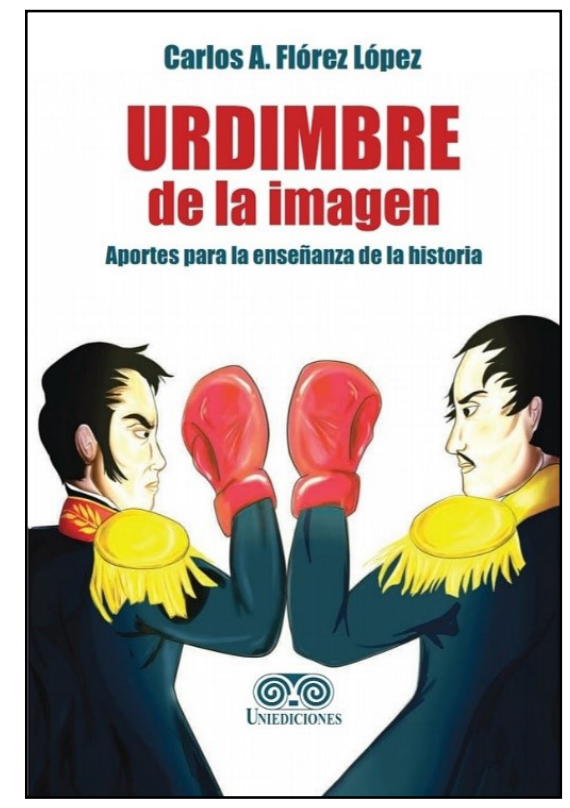

Portada del libro Urdimbre de la imagen. Aportes para la enseñanza de la historia.

Fuente: Flórez López (2020).

Jesús Alfonso Flórez López

Universidad Autónoma de Occidente, Cali, Colombia. jaflorez@uao.edu.co

Cómo citar: Flórez, J. (2021). Reseña del libro Urdimbre de la Imagen. Aportes para la enseñanza de la historia de Carlos A. Flórez López (2020). Ciencias Sociales y Educación, 10(19), 393-395. https://doi.org/10.22395/csye. v10n19a14

Recibido: 10 de octubre de 2020.

Aprobado: 5 de noviembre de 2020. 
Recientemente, fue publicado el texto titulado Urdimbre de la imagen, aportes para la enseñanza de la historia, de autoría de Carlos A Flórez López, el cual nos sumerge en el laberinto de la trama histórica de Colombia.

La pregunta que guía su elaboración es la pedagogía para el aprendizaje de la historia. Esto quiere decir que no es un debate sobre el concepto mismo de historia, sino sobre cómo se realiza la aproximación a esta para entender los hechos o acontecimientos pasados.

Ese interrogante pretende ser resuelto mediante la historia cultural, con lo que el objeto referencial para el conocimiento de la historia, mas no único, es la imagen anclada en el concepto matriz de símbolo. Este abordaje atrae la atención tanto del lector próximo de este objeto de estudio como de aquel que es absolutamente ajeno a la temática de la historia, cuya representación más simple y que repele en muchos casos es la de la cronología y personajes descontextualizados que nos induce al trabajo memorístico.

Una vez explicita esta mirada, el autor nos convoca a una ejecutoria de tal perspectiva de la historia cultural. En este sentido, hace que nuestras miradas se detengan en tres formas de representación que concentran significados con respecto a la interpretación de los hechos acaecidos en contextos determinados.

En primer lugar, presenta la hermenéutica de la caricatura, la cual asume como un registro, diría muy contemporáneo, de la crítica o sátira sobre la actuación de personajes públicos en diversos momentos. Para ello hace, a manera de ejemplo, un acopio de treinta imágenes con las cuales ilustra esta entrada al aprendizaje de la historia de Colombia. Para efectos de dicha ilustración, se ubica en un período específico de dominio conservador y concluye con una referencia al período de la violencia bipartidista.

La segunda aproximación del uso de símbolos es la fijación de la memoria que las diversas sociedades realizan a través de monumentos. En general, estos se traducen en estatuas de cuerpo entero, bustos o cabezas de personajes localizados en escenarios que también recuerdan acontecimientos, bien sean plazas públicas, calles u otros. Este acercamiento es de gran interés para el debate actual sobre el derribamiento de estatuas y monumentos que son leídos por sectores sociales como ofensivos. Esto se debe a que, desde una lectura crítica de la historia, se les mira como objeto de homenaje a quienes fueron protagonistas de hechos degradantes de la humanidad, como la esclavitud, la usurpación de territorios, genocidios; en últimas, herencias de un colonialismo que aún está por superarse. En contrapartida están quienes defienden estos monumentos como un pasado digno de ser enraizado en el pensamiento popular. 
La tercera y última herramienta del aprendizaje de la historia desde los símbolos es el recurso a la imagen a partir de rostros, bien sea mediante la pintura o la fotografía. Aquí, de manera específica, el libro se centra en la representación de individuos en particular, para adentrarse, desde cada uno de dichos rostros, en lo que representaron en una época especifica. Como lo indica literalmente el autor:

Los rostros van delineando con el paso del tiempo el registro de una época, nos puede acercar a las vivencias de sociedades pretéritas y nos permiten colegir rasgos de las identidades sociales y cultuales de aquellos momentos que percibían dichos personajes. (Flórez, 2020, p. 128)

Son tres entradas a la enseñanza de la historia, pero todas esas puertas tienen una llave común para acceder: la imagen o el símbolo, con lo cual se configura un excelente aporte que suscita motivación por la historia en las nuevas y anteriores generaciones. Es probable que debamos ir más allá teniendo en cuenta esta clave de lectura para interpretar el lenguaje contemporáneo de emoticones, trinos y demás simbología propia del lenguaje cibernético.

\section{Referencias}

Flórez, C. (2020). Urdimbre de la Imagen: aportes para la enseñanza de la historia. Uniediciones. 